\title{
PENGGUNAAN TEKNIK GUIDED IMAGERY TERHADAP TINGKAT KECEMASAN SISWA MENGIKUTI AKTIVITAS KONSELING KELOMPOK
}

\author{
Issrahli Shaddri, I Wayan Dharmayana, Illawaty Sulian \\ Prodi Bimbingan dan Konseling Fakultas Keguruan dan Ilmu Pendidikan \\ Universitas Bengkulu \\ issrahlisadri@gmail.com,dharmayana@unib.ac.id, illawaty@unib.ac.id
}

\begin{abstract}
ABSTRAK
Tujuan penelitian ini adalah adalah untuk mendiskripsikan pengaruh teknik guided imagery terhadap tingkat kecemasan siswa mengikuti aktivitas konseling kelompok. Metode dalam penelitian ini adalah metode eksperimen dengan one group pretest-posttest. Populasi dalam penelitian ini adalah siswa kelas VII H SMP N 5 Kota Bengkulu yang berjumlah 28 siswa. Sampel menggunakan purposive sampling. Jumlah sampel adalah 8 siswa. Data hasil penelitian ini dianalisis menggunakan uji z. Hasil penelitian menunjukkan bahwa tingkat kecemasan siswa mengikuti aktivitas konseling kelompok menurun setelah diberikan teknik guided imagery, hal ini ditunjukkan dengan nilai $\mathrm{z}=-$ $2.521^{\mathrm{a}}$ dengan taraf signifikansi $(2$-tailed) sebesar 0.012 yang berarti $0.012<0.05$. Temuan ini menunjukkan bahwa ada pengaruh penggunaan teknik guided imagery terhadap tingkat kecemasan siswa mengikuti aktivitas konseling kelompok di SMP N 5 Kota Bengkulu.
\end{abstract}

Kata kunci: Kecemasan, Siswa, Guided Imagery

\section{INFLUENCE THE USE OF GUIDED IMAGERY TECHNIQUES TO THE ANXIETY LEVEL OF STUDENTS FOLLOWING GROUP COUNSELING ACTIVITIES}

\begin{abstract}
The purpose of this study was to describe influence guided imagery techniques to the level of the students anxiety following group counseling activities. The method in this research is a method of experimentation with approach one group pretest-posttest design. The population in this research is the grad VII H SMP N 5 Kota Bengkuluthat add up to 28 students. Sampling used a purposive sampling technique. The number of sample is 10 students. This research data is analyzed using $z$-test. The result showed that decline level of the students anxiety following group counseling activities, this is indicated by the value of $\mathrm{z}=-2.521^{\mathrm{a}} \mathrm{a}$ significance level (2-tailed) of 0.012 meaning $0.012<0.05$. This findings that there is influence the use of guided imagery techniques to the anxiety level of students following group counseling activitiesin SMP N 5 Kota Bengkulu.
\end{abstract}

Keywords: Anxiety, Students, Guided Imagery 


\section{Pendahuluan}

Pendidikan merupakan proses yang esensial untuk mencapai tujuan dan citacita pribadi individu (Syamsu\& Juntika, 2009:2).Peserta didik adalah individu sedang dalam proses berkembang ke arah kematangan atau kemandirian. Untuk mencapai kematangan tersebut, peserta didik memerlukan bimbingan, karena mereka masih kurang memiliki pemahaman atau wawasan tentang dirinya dan lingkungannya, serta pengalaman dalam menentukan arah kehidupannya (Yarliani, 2014). Menurut Juntika (dalam Tohirin, 2015:11) bahwa penyelenggaraan pendidikan di sekolah termasuk madrasah tidak akan berhasil secara baik apabila tidak didukung oleh penyelenggaraan bimbingan yang baik. Untuk itu bimbingan dan konseling di sekolah menyelenggarakan berbagai layanan guna membantu peserta didik dalam mencapai kematangan diri. Salah satunya yaitu melalui konseling.

Konseling merupakan proses pemberian bantuan yang dilakukan oleh seorang ahli (konselor/pembimbing) kepada individu yang mengalami suatu masalah (konseli) yang bermuara pada terentaskannya masalah yang dihadapi klien. Tidak jarang dalam suatu konseling terutama pada konseling kelompok klien merasa cemas.Freud(dalam Semiun, 2006:87), bahwa kecemasan adalah suatu keadaan perasaan afektif yang tidak menyenangkan (perasaan khawatir dan gelisah) yang disertai dengan sensasi fisik yang memperingatkan orang terhadap bahaya yang akan datang. Sedangkan menurut Prasetyono (dalam Ernawati et al 2015), kecemasan adalah penjelmaan dari berbagai proses emosi yang bercampur baur, yang terjadi manakala seseorang mengalami berbagai tekanan-tekanan atau ketegangan (stress) seperti perasaan (frustasi) dan pertentangan batin (konflik batin). Kecemasan siswa mengikuti aktivitas konseling kelompok dapat terjadi karena rasa tidak nyaman karena siswa takut jika dirinya dinilai buruk oleh orang lain, melakukan hal-hal tidak sopan atau memalukan dan hal-hal memalukan tentang dirinya diketahui orang lain. Ini menyebabkan siswa akan selalu menilai dirinya negatif dan menganggap keadaannya saat sekarang atau yang akan datang akan selalu menderita, serta menganggap bahwa orang lain selalu lebih baik daripada diri mereka sendiri (Wilding, 2013). 
Kecemasan timbul karena adanya suatu bahaya yang mengancam diri seseorang (Kusuma dalam Ari,2012). Kecemasan bisa berbentuk ketakutan akan pandangan orang lain terhadap kita atau hal lainnya yang membuat kita khawatir. Dalam aktivitas konseling kelompok siswa menunjukkan kecenderungan kurang terbuka dengan masalah yang dihadapi dirinya. Siswa mengganggap hal yang mereka hadapi akan diketahui oleh teman-teman yang lain jika mereka berurusan dengan konselor di sekolah. Kecemasan yang dialami oleh siswa mengikuti aktivitas konseling kelompok perlu diatasi agar tidak menjadi masalah lainnya. Mengatasi masalah kecemasan siswa mengikuti aktivitas konseling kelompok berguna dalam membantu siswa untuk bisa menjadi pribadi yang lebih terbuka lagi dan dapat berbagi cerita ataupun masalahnya yang nantinya akan dibahas melalui dinamika kelompok. Kecemasan terjadi sebagai akibat dari ancaman terhadap harga diri yang sangat mendasar bagi keberadaan individu (Walasaryet al 2015:511). Beberapa gejala timbulnya kecemasan seperti yang dikutip oleh Kusumadewi (2008), berdasarkan Hamilton Anxiety Rating Scale (HARS) yaitu: (a) Gejala psikologis: kecemasan meliputi gelisah, konsentrasi terganggu, cepat marah, merasakan adanya tanda-tanda bahaya, insomnia, libido menurun dan mudah tersinggung, (b) Gejala fisik: kecemasan meliputi jantung berdebar, berkeringat, rasa sesak napas, gangguan tidur, mudah lelah, sering kencing, dan mulut kering.

Cara sederhana dan efektif untuk mengelola gejala kecemasan atau stres adalah melalui teknik relaksasi.Menurut Black dan Martassarin seperti dikutip oleh Deswita et al (2014:111),guided imagery merupakan suatu teknik relaksasi non-farmakologis yang bermanfaat untuk menurunkan kecemasan, kontraksi otot, dan memfasilitasi tidur.Guided Imagery adalah teknik relaksasi yang mudah dan sederhana yang dapat membantumengatasi stress dengan cepat dan mudah dan mengurangi ketegangan di tubuh. Teknik ini dapat membantu untuk lebih mengakses hikmat batin seseorang (Prabu, 2015:56).Penelitian Kalsum et al (2012), menunjukkan bahwa teknik guided imagery dapat menurunkan tingkat kecemasan pada klien dengan insomnia usia 20-25. Setelah dilakukan teknik guided imagery diperoleh $81 \%$ subjek penelitian mengalami penurunan tingkat 
kecemasan dan 19\% subjek penelitian tingkat kecemasannya tetap. Penelitian yang dilakukan oleh Kamora et al (2012),mengenai Efektifitas Teknik Relaksasi Guided Imageryterhadap Pemenuhan Rata-Rata Jam Tidur Pasien di Ruang Rawat Inap Bedah menunjukkan bahwa teknik relaksasi guided imagery berpengaruh terhadap peningkatan rata-rata jam tidur pada pasien rawat inap.

Menerapkan guided imagery pada anak atau remaja harus menggunakancontoh konkret sehari-hari yang bisa dipahami, misalnya membayangkan mereka sedang bermain layang-layang, menikmati makan es krim yang lezat. Ketika saat keadaannya takut terhadap sesuatu dapat diajarkan seolaholah mereka memiliki kekuatan seperti superman, ksatria baja hitam, yang mampu mengatasi rasa takutnya (Triantoro, 2004:82). Selain itu pengaturan posisi yang nyaman pada klien merupakan hal penting dalam membantu klien membayangkan imajinasinya. Dengan suara yang lembut, klien dibawa menuju tempat spesial dalam imajinasi mereka (misalnya ke pantai pasir putih, air terjun, taman bunga, dan pegunungan).

Luísand Kolcaba (2009), menjelaskan guided imagery membantu melawan pikiran yang kaku, otomatis, dan putus asa.Pengertian ini membantu memperkuat harga diri dan transendensi pribadi. Harga diri dan transendensi memberikan kontribusi pada pengalaman yang lebih positif. Imajinasi menciptakan jembatan antara pikiran dan tubuh, menghubungkan persepsi, emosi, dan respons psikologis, fisiologis, dan perilaku. Tujuan penelitian ini adalah untuk mendeskripsikan pengaruh guided imagery terhadap tingkat kecemasan siswa mengikuti aktivitas konseling kelompok.

\section{Metode Penelitian}

Penelitian yang digunakan adalah pra-experimental design, yang mana desain yangdigunakandalam penelitian ini adalah one-group pretest-posttest. Pertama-tama dilakukan tes awal (pre-test) untuk mengukur tingkat kecemasan siswa. Kemudian diberikan teknik guided imagery. Diakhiri dengan dilakukan pengukuran kembali (post-test), dengan kuesioner yang sama seperti yang digunakan pada tes awal (pre-test).Populasi dalam penelitian ini adalah siswa 
kelas VII H SMP N 5 Kota Bengkulu sebanyak 28 siswa dengan rentang waktu penelitian dari tanggal 26 Maret - 5 Mei 2018.

Penentuan sampel menggunakan purposive sampling, yang mana sampel berjumlah 8 orang yang diambil berdasarkan tingkat skor kecemasan tertinggi. Penelitian terdiri dari variabel terikat tingkat kecemasan siswa mengikuti aktivitas konseling kelompok dan guided imagery merupakan variabel bebas.

Penelitian dilaksanakan sebanyak 5 kali pertemuan dengan sampel terpilih, dengan waktu 1x40 menit. Kegiatan dilakukan dengan rangkaian tahap-tahap: (a) tahap pembentukan, (b) tahap peralihan, (c) tahap kegiatan, (d) tahap pengakhiran. Setelahnya dilaksanakan evaluasi dan tindak lanjut untuk pertemuan berikutnya.

Tingkat kecemasan siswa diukur menggunakan kuesioner kecemasan, pengukuran variabel dilakukan sebelum dan sesudah treatment. Analisis meliputi uji validitas dan reliabilitas, serta pengujian hipotesis menggunakan uji z,ini digunakan untuk mencari pengaruh penggunaan teknik guided imagery terhadap tingkat kecemasan siswa mengikuti aktivitas konseling kelompok. Untuk menguji hipotesis digunakan uji non parametrik dengan rumus Wilcoxon Signed Rank

\section{Hasil dan Pembahasan}

Sesuai dengan tujuan, yaitu untuk mengetahui pengaruh penggunan teknik guided imagery terhadap tingkat kecemasan siswa mengikut aktivitas konseling kelompok. Sampel diambil berdasarkan skor kuesioner skala kecemasan yang memiliki tingkat kecemasan tinggi. Penjabaran dari hasil pre-test pada siswa populasi dapat dilihat pada Tabel 1 tentang distribusi frekuensi pre-test tingkat kecemasan siswa mengikuti aktivitas konseling kelompok. Di mana dari 28 orang siswa yang diberikan kuesioner mendapatkan hasil dengan kategori sangat rendah sebanyak 2 orang dengan persentase $7.14 \%$, kategori rendah 7 orang dengan persentase $25.00 \%$, kategori sedang 12 orang dengan persentase $42.86 \%$, dan kategori tinggi 7 orang dengan persentase $25.00 \%$. Dari hasil ini dapat dikatakan bahwa rata-rata tingkat kecemasan siswa mengikuti aktivitas konseling kelompok berada pada kategori sedang. 


\section{Tabel 1}

Distribusi frekuensi pre-test tingkat kecemasan siswa mengikuti aktivitas konseling kelompok

\begin{tabular}{ccc}
\hline Kategori & Frekuensi & Persentase \\
\hline Sangat Tinggi $(>130)$ & 0 & 0 \\
\hline Tinggi $(105-129)$ & 7 & $25.00 \%$ \\
\hline Sedang $(80-104)$ & 12 & $42.86 \%$ \\
\hline Rendah $(55-79)$ & 7 & $25.00 \%$ \\
\hline Sangat Rendah $(30-54)$ & 2 & $7.14 \%$ \\
\hline Total & 28 & $100 \%$ \\
\hline
\end{tabular}

Kecemasan mengikuti aktivitas konseling kelompoksiswa disebabkan oleh beberapa faktor, seperti faktor fisik (keringat bercucuran, jantung berdebar, mulut kering, tangan terasa dingin, pencernaan terganggu) dan faktor psikis (rendah diri, emosional, takut, gugup, konsentrasi terganggu).

Konseling kelompok kemudian dilakukan dengan mengajak 8 siswa yang memiliki skor tingkat kecemasan tinggi. Treatment berupa konseling kelompok dan guided imagery diberikan guna membantu siswa dalam menurunkan tingkat kecemasannya mengikuti aktivitas konseling kelompok. Tiap pertemuan kegiatan konseling kelompok siswa mengungkapkan masalah yang mereka alami dan kemudian diikuti dengan memberikan teknik guided imagery dalam membantu menurunkan tingkat kecemasan siswa mengikuti aktivitas konseling kelompok. Setelah 5 pertemuan yang dilakukan kemudian diukur kembali tingkat kecemasan siswa mengikuti aktivitas konseling kelompok untuk melihat hasil dari post-test.

Berdasarkan hasil pre-test yang dilakukan diambil 8 siswa yang memiliki skor tingkat kecemasan tinggi untuk diberikan treatment. Selanjutnya, hasil perbandingan skor tingkat kecemasan siswa sebelum dan setelah diberikan perlakuan. Seperti yang terlihat pada Tabel 2 tentang perbandingan skor pre-test dan post-test kecemasan siswa mengikuti aktivitas konseling kelompok. Dapat dilihat bahwa pada skor pre-test tidak ada perbedaan yang signifikan antar siswa. Begitu juga dengan skor post-test. Tetapi dalam hal ini terjadi penurunan tingkat kecemasan yang ditunjukkan dengan skor mean 113.5 sebelum menjadi 75.0 setelah

treatment. 
Tabel 2

Perbandingan skor pre-test dan post-test kecemasan siswa mengikuti aktivitas konseling kelompok

\begin{tabular}{cccccc}
\hline No & Inisial Siswa & Skor Pre-test & Kategori & Skor Post-test & Kategori \\
\hline 1 & RC & 100 & Sedang & 67 & Rendah \\
\hline 2 & DN & 122 & Tinggi & 86 & Sedang \\
\hline 3 & CA & 113 & Tinggi & 69 & Rendah \\
\hline 4 & RD & 124 & Tinggi & 81 & Sedang \\
\hline 5 & DA & 119 & Tinggi & 68 & Rendah \\
\hline 6 & AA & 108 & Tinggi & 78 & Rendah \\
\hline 7 & RB & 107 & Tinggi & 78 & Rendah \\
\hline 8 & DT & 115 & Tinggi & 73 & Rendah \\
\hline \multicolumn{7}{c}{ Jumlah } & 908 & & 600 & \\
\hline & Tertinggi & 124 & & 86 & \\
\hline \multicolumn{7}{c}{ Terendah } & 100 & & 67 & \\
\hline & Mean & 113.5 & Tinggi & 75.0 & Rendah \\
\hline \multicolumn{7}{c}{}
\end{tabular}

Perbandingan dilakukan pada skor kecemasan sebelum dan sesudah treatment. Untuk melihat pengaruh dari treatment yang diberikan dalam mengurangi tingkat kecemasan siswa. Ini dapat dilihat pada Tabel 3 tentang hasil perhitungan uji z.

Tabel 3

Hasil Perhitungan Uji z

\begin{tabular}{lr} 
& POSTEST - PRETEST \\
\hline$Z$ & $-2.521^{\mathrm{b}}$ \\
\hline Asymp. Sig. (2-tailed) & .012 \\
\hline
\end{tabular}

Berdasarkan hasil uji z dengan $\mathrm{z}=-2.521^{\mathrm{a}}$ dan signifikansi (2-tailed) sebesar 0.012 yang artinya $0.012<0.05$. Maka dapat dikatakan bahwa terdapat pengaruh penggunaan teknik guided imagery terhadap tingkat kecemasan siswa mengikuti aktivitas konseling kelompok di SMP N 5 Kota Bengkulu.

Mekanisme terjadinya penurunan tingkat kecemasan siswa selama guided imagery dimulai dengan mengajak responden untuk mengungkapkan masalah/ hal yang mengganggu mereka, yang kemudian bersama dibahas dalam proses konseling kelompok. Setelahnya responden akan diberikan ruangan yang nyaman dan tenang lalu dipandu untuk merelaksasikan diri responden dan mengosongkan pikiran. Responden diminta untuk memposisikan diri di posisi yang membuat 
responden nyaman lalu menutup mata. Peneliti akan memandu responden untuk merasakan rasa rileks dengan nafas dalam dan memberi arahan untuk mengimajinasikan hal-hal yang disukai responden dalam memberikan rasa nyamandan rileks. Responden diminta untuk tetap menjaga pola nafasnya agar tetap rileksdan merasa nyaman.

Peneliti memberikan motivasi melalui proses membayangkan sesuatu yang disukai responden, Setelah diberikan guided imagery responden diminta untuk mengungkapkan perasaan dan kesannya setelah diberikan treatment. Dalam beberapa pertemuan dan pelaksanaan yang dilakukan berikut beberapa ungkapan verbatim siswa setelah diberikan teknik guided imagery:

"saya merasa lebih rileks setelah melaksanakan perjalanan imajinasi".

"berada dalam perjalanan imajinasi saya merasa tenang dan menikmati suasana santai".

Selanjutnya ungkapan verbatim siswa setelah diberikan teknik guided imagery dengan tambahan musik:

"perasaan saya kali ini terasa lebih nyata karena ada tambahan musik, jadi imajinasi yang saya lakukan sedikit lebih terasa".

"dibandingkan dengan yang pertama suasana pantainya yang sekarang lebih terasa”.

Pelaksanaan 2 treatment akhir siswa diminta untuk mengimajinasikan sendiri berbagai tempat yang bisa membuat ia nyaman, dan meminta mereka menceritakan pengalamannya. Berikut ungkapan verbatim beberapa siswa:

"merasakan suasana pagi hari di pantai bersalju. Sekarang saya merasa lebih tenang dan rileks".

"saya membayangkan saya berada di kebun teh, menikmati suasana kebun, berlarian dan memetik daun teh. Saya merasa senang".

"saya menikmati suasana laut dan sedang berada di atas kapal yang tidak tahu arah. Tetapi saya bersama dengan rombongan-rombongan lain di kapal. Perasaan saya sekarang senang".

"saya terbayangkan berada disebuah pantai yang jika airnya dipegang mengeluarkan cahaya. Saya merasa sangat senang berada ditempat tersebut. Saya pergi bersama dengan adek saya".

Jika dilihat siswa dapat merasa kembali rileks dan merasa senang saat berada dalam kondisi ternyaman mereka. Serta pengalaman-pengalaman menyenangkan yang mereka rasakan membuat kondisi mereka menjadi lebih baik 
lagi. Hal selanjutnya yang dilakukan setelah evaluasi adalah menetapkan komitmen responden untuk dapat mengingat sesi ini dan dapat kembali kapan saja ke kondisi yang membuat responden dapat merasa nyaman dan rileks. Dilakukannya guided imagery ini secara berkelanjutan dirasakan siswa dalam membantu mereka dalam menurunkan tingkat kecemasan yang mereka rasakan. Pertemuan-pertemuan yang dilaksanakan sebanyak 5 kali terlihat perkembangan perilaku dari pada siswa dimana mereka lebih mulai aktif dan mulai berani untuk membuka dirinya dalam mengungkapkan permasalahan yang mereka hadapi terkait kecemasan-kecemasan yang dialaminya.

Berdasarkan analisis data diketahui hasil tingkat kecemasan siswa mengikuti aktivitas konseling kelompok menurun setelah diberi treatment. 8 orang responden mengalami penurunan tingkat kecemasannya.Watanabe et al (2006), menyebutkan bahwaguided imagery meningkatkan mood positif dan menurunkan mood negatif individu secara signifikan.

Penurunan tingkat kecemasan siswa tersebut dapat dilihat dari hasil pre-test dan post-test yang mengalami penurunan skor. Berdasarkan hasil uji hipotesis, penggunaan teknik guided imagery menunjukkan gambaran bahwa setiap siswa yang diberikan treatment berupa guided imagerymengalami penurunan tingkat kecemasannya.

\section{Kesimpulan}

Guided imagery efektif dalam membantu menurunkan tingkat kecemasan siswa mengikuti aktivitas konseling kelompok. Ini ditujukkan dengan hasil analisis deskriptif skor mean sebelum treatment 113.5 menjadi 75.0 setelah treatment. Dari hasil uji $\mathrm{z}$ dengan $\mathrm{z}=-2.521^{\mathrm{a}}$ dan signifikansi (2-tailed) sebesar 0.012 yang artinya $p<0.05$ menunjukkan bahwa ada pengaruh penggunaan teknik guided imagery terhadap tingkat kecemasan siswa mengikuti aktivitas konseling kelompok di SMP N 5 Kota Bengkulu.

Bagi siswa, dapat membantu dalam menurunkan tingkat kecemasannya dengan cara melakukan imajinasi-imajinasi yang dapat membuat kondisi rileks dan tenang. Karena guided imagery sebagai teknik relaksasi yang mudah untuk 
digunakan. Bagi guru, untuk dapat melaksanakan layanan konseling kelompok lebih rutin dan sesuai dengan permasalahan yang dialami siswa, guna dapat menunjang keoptimalan pelaksanaan layanan bimbingan dan konseling di sekolah. Bagi penelitian lanjutan dapat menggunakan penelitian ini sebagai bahan acuan untuk mengembangkan penelitian selanjutnya menambah variabel-variabel lain yang bisa memperluas penelitian.

\section{Daftar Pustaka}

Ari, L. (2012). Hubungan Antara Tingkat Kecemasan Dengan Tingkat Dispepsia Menjelang Ujian Nasional Pada Siswa Kelas IX Di SMP Negeri 1 Banyudono Boyolali Tahun 2012. Naskah Publikasi Fakultas Kedokteran Universitas Muhammadiyah Surakarta.

Deswita., Asterina, M.S., \&Hikmah, U. (2014). Pengaruh Teknik Relaksasi Imajinasi Terbimbing (Guided Imagery) Terhadap Pemenuhan Kebutuhan Tidur Anak Usia Sekolah di Ruang Rawat Inap Anak RSUD Prof. Dr. Ma. Hanafiah SM Batusangkar. Ners Jurnal Keperawatan, 10(1), 110-117.

Ernawati, N \& Hernowo, D. (2015). Pengaruh Pemberian Pendidikan Kesehatan tentang Proses Persalinan Terhadap Tingkat Kecemasan Ibu Primigravida Trimester III. Jurnal Kesehatan Hesti Wira Sakti, 3(3), 45-49.

Kalsum, U., Herawati, T., \&Hidayati, F. (2012). Pengaruh Teknik Relaksasi Guided Imagery terhadap Penurunan Tingkat Kecemasan Wanita dengan Insomnia Usia 20-25 Tahun.Jurnal Makalah Kesehatan FKUB. Diunduh dari http://www.google.co.id/\#hl=id\&gsnf=3\&pq=pengaruh\%20teknik\%2 0 relaksasi\%20tanggal 28 Januari 2018.

Kamora, M., Utomo, W., Hasanah, O. (2012). Efektifitas Teknik Relaksasi Guided Imagery Terhadap Pemenuhan Rata-Rata Jam Tidur Pasien Di Ruang Rawat Inap Bedah. Diunduh dari https://repository.unri.ac.id/ jspui/bitstream/ 123456789/1784/1/EFEKTIFITAS\%20TEKNIK\%20 RELAKSASI $\% 20$ \%20IMAGERY\%20TERHADAP\%20PEMENUH.pdftanggal 10 Febuari 2018.

Kusumadewi, S. (2008). Aplikasi Fuzzy Total Integral Pada Hamilton Anxiety Rating Scale (HARS). Seminar Nasional Aplikasi Teknologi Informasi 2008 (SNATI 2008), ISSN: 1907-5022. Hal: 73-76.

Luís, J., Apóstolo, A., \& Kolcaba, K. (2009). Comfort , Depression , Anxiety , and Stress Depressive Disorders. Archives of Psychiatric Nursing,O(0), 1-9. 
Prabu, P.K \& Subhash, J. (2015). Guided Imagery Therapy. Journal of Nursing and Health Science, 4(5), 56-58.

Semiun, Y. (2006). Teori Kepribadian dan Tetapi Psikoanalitik FREUD. Yogyakarta : Kasinius.

Syamsu, L.N \& Juntika N. (2009). Landasan Bimbingan dan Konseling. Bandung: PT Remaja Rosdakarya.

Tohirin. (2015). Bimbingan dan Konseling di Sekolah dan Madrasah. Jakarta: Raja Grafindo Persada.

Triantoro. (2004). Terapi Kognitif-Perilaku untuk Anak. Yogyakarta: Graha Ilmu.

Walasary, A.S., Dundu.,\& Kaunang T. (2015). Tingkat Kecemasan Pada Siswa Kelas XII Sma Negeri 5 Ambon Dalam Menghadapi Ujian Nasional. Jurnal e-Clinic (eCl), 3(1), 510-515.

Watanabe, E., Fukuda, S., Hara, H., Maeda, Y., Ohira, H., Shirakawa, T. (2006). Differences In Relaxation by Means of Guided Imagery in a Healthy Community Sample. Jurnal: Alternative Therapies, 12(2), 60-65.

Wilding, C \& Milne, A. (2013). Cognitive Behavioral Therapy. Jakarta: Indeks.

Yarliani. (2014) . Peran Guru Bimbingan dan Konseling Membantu mengatasi Masalah Hubungan Sosial Siswa di Madrasah Tsanawiyah Negeri Banjarmasin Selatan Kota Banjarmasin. Jurnal: Guidance and Counseling, l(1), 46-54. 